UDC 811.111'42: 821.111 "15"

DOI https://doi.org/10.32838/2710-4656/2021.1-2/48

Mykytiuk I. M.

Yuriy Fedkovych Chernivtsi National University

Lesinska O. M.

Yuriy Fedkovych Chernivtsi National University

\title{
NOMINATIONS OF PERSONAGES IN PORTRAIT DESCRIPTIONS: CONTRASTIVE STUDY (BASED ON UKRAINIAN AND ENGLISH LITERARY DISCOURSES)
}

The article explores the issue of the characters 'portrait descriptions in Ukrainian (stories by Ivan Nechuy-Levytsky) and English (short stories by William Somerset Maugham) literary discourses. The current state of research of the portrait as a genre of belles-lettres discourse is described. Particular attention is focused on identification, interpretation, and contrastive analysis of the key lexemes which form the basis of the characters'verbal portraits. The presented research is topical, since it makes an attempt at a contrastive study of literary portraiture nominations in Ukrainian and English belles-lettres texts. The undertaken contrastive analysis elucidates peculiarities of language worldviews of the speakers of the Ukrainian and the English languages. We view literary portraiture as a powerful means of verbal representation of characters both in statics and dynamics, which is achieved through skillful depiction of their distinctive features and essential characteristics. Portrait descriptions in both Ukrainian and English literary discourses may be grouped according to the following characteristics of the personages: age (літній; a man of forty); height and constitution (гнучка, як тополя; tall, thin man); hair color and hair style (товсті чорні коси; red hair); facial features (повновида; fleshy face); skin condition (лице, свіэе, як ягода; freckled skin); form and color of eyes (сині, як небо, очі; fine dark eyes); traits of character (бриклива; reserved); manner of behavior and speech (пишала губи; raucous voice); clothes and adornments (в квітках та стрічках; tweeds and heavy boots); background, social status and profession (був шевцем, стрільщем; wealthy banker). The above-listed characteristics fully coincide in Ukrainian and English belles-lettres discourses. However, in W. S. Maugham's literary discourse we have additionally traced portraiture nominations denoting physical defects of the personages. Individual characteristics represented in portrait descriptions are capable of creating impressive, colorful and convincing images of the personages, as well as providing the readers with some additional knowledge about the characters' personalities.

Key words: portrait characteristics, characterization, literary character, literary image.

Statement of the research problem. No literary character comes into literary "existence" without being (concisely or extensively) verbally portrayed. The writers, either explicitly or implicitly, demonstrate their attitude to the personages by way of describing their physical appearance, dress, gestures, manners, etc. The problems of creating a character's literary portrait, as well as analysis of its role in the structure of a belles-lettres text claim attention of both linguists (A. Abdullina [1], T. Nasalevych [8], Ye. Varlakova [2], T. Vdovenko [3]) and literary critics (B. Galanter [5], W. Steiner [14], V. Trykov [10]). The topicality of this research is stipulated by an attempt to undertake a contrastive study of literary portraiture nominations in Ukrainian and English belles-lettres texts. Such study may help to shade some light at peculiarities of language worldviews of speakers of the Ukrainian and the English languages.

Analysis of recent researches and publications. Portrait in literature is defined in the "Literary Encyclopaedia of Terms and Notions" as a description or creation the impression from the outer image of the personage, mainly his or her face, figure, clothes, bearing [7, p. 762]. Similar definition may be found in the "Dictionary of Literary Terms", an earlier publication, which is, though, somewhat extended with regard to portrait description typology. According to this lexicographic source, portrait description may be realistic and psychological, the latter serving the purpose of exposing the character and the inner world of the personages through their outer appearance [9, p. 275]. 
Having undertaken a comprehensive analysis of portrait descriptions in memoirs and biographies, A. Halych claims that the literary genre of a documentary determines the quality of portraiture since the aim of nonfiction is to create the portrait of a real person backed by documents and facts and devoid of any subjectivity [6, p. 6].

O. Shinkevich analyses portrait-description as one of the main artistic devices for portrayal of a literary character and comes to the conclusion that besides reflecting social and psychological background of the personages portrait-descriptions are capable of exposing their national identity [11, p. 83].

According to N. Venzhynovych, phraseological units used in descriptions of literary characters, are capable of bearing a considerable linguocultural potential since they serve to create a unique phraseological worldview of the speaker [4, p. 360].

C. Theobald traces some ties between literary and painted portraits, investigates interaction between literary portraiture and a literary text, and postulates the changing status of verbal descriptions in early French fiction [15]. E. Fowler introduces the term "human figure in words" and suggests her own method of analysis of this phenomenon in early English writing [12, p. 3]. W. Steiner speaks about the anomalous character of portrait as a genre claiming that "it is governed simultaneously by aesthetic and referential norms" [14, p. 111]. At the same time, verbal portraits are constructed in such a way that they are capable of evoking "a 'vivid' image of the person depicted" [14, p. 111].

According to E. Fowler, verbal portraiture serves as one of the means of characterization [12, p. 16]. A similar idea is put forward by E. Heier in the article "The literary portrait" as a device of characterization" [13]. We fully agree with the observations presented above and consider literary portraiture a powerful means of verbal representation of characters both in statics and dynamics, which is achieved through skillful depiction of their distinctive features and essential characteristics.

Setting of the objective. The objective of the article is to identify, interpret and compare, with the help of a contrastive analysis, the key portraiture nominations used in descriptions of literary characters in Ukrainian and English belles-lettres texts. The research is based on the stories by I. Nechuy-Levytsky and W. Somerset Maugham. Both authors were first published at the end of the $19^{\text {th }}$ - the beginning of the $20^{\text {th }}$ century.

Discussion. Portrait descriptions in the works by both Ivan Nechuy-Levytsky and W. S. Maugham may be grouped according to different characteristics denoted by them. Let's examine each group separately.
The age of the characters in Ukrainian discourse is described mainly by the lexemes "young" and "old", for example: «молоді парубки» [17, p. 154]; «старий Омелько» [17, р. 155]; «вже не молода, але й не стара» [17, p. 157]; «літній чоловік» [17, р. 580]. W. S. Maugham is more specific as to the age of his personages: as a rule, the exact age is mentioned, for example: "a man of forty" [18, p. 14]; "twenty-seven perhaps" [18, p. 18]; "a man between forty and fifty" [18, p. 64]; "in the comfortable forties" [18, p. 128].

As to the description of height and constitution, portraits in Ukrainian discourse are mainly focused on stature: «високі, рівні станом» [17, p. 154]; «висока на зріст, рівна станом, але не дуже тонка» [17, p. 162]; shoulders and chest: «широкий в плечах» [17, p. 154]; «3 дужсими плечима, 3 козачькими грудьми» [16, p. 105]; hands: «здорові загорілі жсилаві руки» [17, p. 153]; legs: «з кремезнили ногами» $[17$, p. 162]. The vividness of description is achieved with the help of trite similes, characteristic of the Ukrainian language: «рівна, як струна, гнучка, як тополя» [17, p. 199]; «великий, як верства» [16, p. 103].

Emphasis is English discourse is laid mainly upon height and figure, for example: "very tall and thin, with long limbs loosely jointed" [18, p. 16]; "very tall, thin man" [18, p. 49]; "tall rather than otherwise and very spare" [18, p. 64]; "with an ungainly figure that made him look squat" [18, p. 164]; "a little man, without angles, plump" [18 p. 66]; "very short, but thick-set" [18, p. 68].

The description of hair color and hair style of the characters in both types of discourse is rather varied with much attention being paid to its length and quality: «русяві дрібні кучері на голові» [17, p. 154]; «з чорними косами» [17, p. 162]; «з густими русявими кучерями» [17, р. 283]; «товсті чорні коси тричі обплітали їі голову» [16, p. 34]; "very red hair" [18, p. 14]; "brown, dull hair very elaborately arranged" [18, p. 14]; "hair very long" [18, p. 16]; "hair, as a rule so elaborately arranged, was tumbling untidily over her neck" [18, p. 32]; "a thick mat of black, wavy hair, very sleek and shiny" [18, p. 151].

A number of comparisons used in the descriptions of the personages' hair make the portrait particularly vivid: «кучеряве посічене волосся стирчало на голові, як пух, і блищало сивиною» [17, p. 154]; «необстрижені волоски на висках закручувались кучерями, неначе гарний смушок» [17, p. 288].

Both authors choose to portray some characters as being bald, for example: «з лисиною на всю голову» [17, p. 158]; "with a bald patch on the crown" [18, p. 14]; "with a completely bald head" [18, p. 74]. 
In the description of the characters' facial features in Ukrainian discourse much attention is paid to the form of the face: «широке лице було сухорляве» [17, p. 153-154]; «довгообразі» [17, р. 154]; «довгасте лиие» [17, р. 154]; «довгообраза, повновида» [17, р. 199]; «на делікатному виду» [17, р. 283]; «лице <...> зверху широке, внизу узьке» [17, p. 290]; form of the nose: «з довгими, тонкими, трошки горбатими носами» [17, p. 154]; «з тонким носиком» [17, p. 199]; lips: «з тонкими губами» [17, р. 154]; «з рум'яними губами» [17, p. 154]; «губи були повні та червоні, як калина» [17, p. 199]; еyebrows: «чорноброва» [17, p. 162]; «нечорнобровий» [17, p. 162]; «брови чорненькі» [17, p. 187]; «брови полиняли» [17, p. 187]; «веселі тонкі чорні брови, густі-прегусті, як шовк» [17, p. 199]. Details about fullness of the face, nose and mouth are provided in the descriptions of characters in English discourse as well: "pinched face" [18, p. 14]; "fleshy face" [18, p. 107]; "a rather large Semitic nose" [18, p. 164]; "her big nose, large mouth, and fleshy face" [18, p. 168]; "a straight nose" [18, p. 175]; "a fleshy, hooked nose" [18, p. 196], but there are also details about the personages' cheeks and chins: "the cheeks hanging on each side in great dew-laps, and three vast chins" [18, p. 107]; "sallow, sunken cheeks" [18, p. 109].

The personages' skin condition in both Ukrainian and English discourses is characterized with regard to complexion and wrinkles: «бліде, наче лице в чения» [17, p. 153-154]; «на сухому високому лобі набігали густі дрібні зморики» [17, р. 154]; «лице було рум'яне» [17, р. 154]; «жовте, як віск, жовте, як лице в чения» [17, p. 158]; «личко біленьке» [17, р. 187]; «личко моє змарніло» [17, р. 187]; «лице, свіже, як ягода» [17, р. 199]; «глибокі зморшки на щоках, на лобі, поморщена темна потилиия од гарячого сония» [16, p. 435]; "red, freckled skin" [18, p. 14]; "deeply burned by the sun" [18, p. 49]; "skin was brown" [18, p. 53]; "brown skin had an exquisite translucency" [18, p. 67]; "very wrinkled" [18, p. 74].

While describing the personages' eyes, I. NechuyLevytsky mentions not only their color, but provides some additional characteristics as well, for example, resemblance to parents' eyes, expression of the eyes, etc.: «з батьківськими карими гострими очима» [17, p. 154]; «сині, як небо, очі» [17, р. 154]; «з темними блискучими, як терен, облитий дощем, очима» [17, p. 162]; «гострі, якніж, очі» [17, p. 167]; «над темними ясними й незвичайно спокійними очима» $[17$, p. 288]. W. S. Maugham particularly emphasizes size and expression of the eyes: "eyes were large and somber" [18, p. 109]; "twinkled little bright eyes" [18, p. 129]; "fine dark eyes" [18, p. 175]; "very large, lustrous and liquid eyes" [18, p. 196].

No less important in literary portraits are the traits of character of the personages. In both types of discourse they serve as a means of revealing the authors' attitude to the characters, for example: «дуже богомільний» [17, p. 155]; «трохи бриклива, i в неї серие з перием» [17, р. 156]; «розум з завзяттям і трохи з злістю» [17, p. 162]; «з поетичною душею, з ласкавим серием» [17, p. 204]; «добрий, богобоящий, не гордий $i$ до людей привітний та ласкавий» [17, р. 282]; «тиха та смутна» [16, p. 34]; "of an argumentative mind" [18, p. 13]; "she gave no impression of foolishness, rather of extreme alertness" [18, p. 14]; "by nature reserved and even morose" [18, p. 16]; "her truthfulness, her rigid sense of honour, her fearless outlook" [18, p. 40]; "he had high spirits, an unfailing gaiety, and incredible charm" [18, p. 79].

The characters are also indirectly characterized through manner of their behaviour and speech, for example: «пишала губи, осміхалась, сипала облесливими словами, наче дрібним горохом» [17, р. 157]; «лаялась і кричала на ввесь рот» [17, p. 157]; «несамохіть вкидала слова пісень» [17, p. 204]; «міряв хату широченними ступенями» [16, p. 103]; «ступав кожною ногою, ніби думаючи, як треба ступить, все ходив задумавшись» [16,p. 105]; "voice, high, metallic, and without inflexion" [18, p. 14]; "he talked a great deal in a raucous voice" [18, p. 82]; "his Western accent" [18, p. 101].

Much attention is paid to clothes and adornments of the characters. I. Nechuy-Levytsky' story "Clouds" starts with a group portrait of young noblemen on their way from Tula to Kyiv: «На молодих паничах були сіртуки з темної парусини з чорними роговими гудзиками, суконні широкі й круглі картузи» [16, p. 101]. One of the main characters of the story "The Kaydash Family" Motria dresses exquisitely: «в квітках та стрічках. Червона запаска, червоні чоботи, як жар» [17, p. 166]. Her adornments are compared with "pure gold" («як щире золото» [17, p. 166]). A few other examples are: «в білій сорочиі з широкими рукавами» [17, р. 153]; «жовтогарячий кісник на голові та червоне намисто на шиї» [17, р. 162]; «в зелену спідницю, в червону запаску, <..> у зелений з червоними квітками горсет, <..> в червоні чоботи, <..> добре намисто» [17, p. 166]; «довгий синій суконний сюртук з широким коміром» [17, p. 289]; «чорна сукня $з$ илейфом» [17, р. 527]. Less colorful are the descriptions of the characters' clothes 
and adornments in W. S. Maugham's stories: "a pair of dungarees instead of a lava-lava” [18, p. 114]; "tweeds and heavy boots and whenever she could went about bareheaded" [18, p. 129]; "a doublebreasted dinner jacket, a little too much waisted, and a butterfly tie a good deal too large" [18, p. 151]; "full evening dress, with a white tie" [18, p. 155].

While describing the characters, I. NechuyLevytsky also takes into account their background, social status and profession, for example: «замолоду довго служила в дворі, у пана» [17, р. 157]; «він був дяк» [17, p. 304]; «я й кравиюював, і кушнірував, був шевием, стрільщем, а далі кинувся до иимбал, став музикою» [16, p. 86]; «не панія» [16, p. 479]; «віковічного хлібороба-кріпака» [16, р. 485]; «він був сам $і$ хазяїном, $і$ отаманом ватаги» [16, p. 490]. It's quite natural that background, social status and profession of personages in W. S. Maugham's discourse are completely different: "in her veins flowed the best blood in Chicago" [18, p. 42]; "a wealthy banker, prominent in his church, a philanthropist" [18, p. 44]; "he was born in Honolulu and his father had a large store" [18, p. 64]; "he was called Wheeler, but though he had that English surname there was not a drop of white blood in him" [18, p. 70].

W. S. Maugham chooses to describe some physical defects of the characters as well, for example: "he had a bad limp" [18, p. 68]; "a very pronounced harelip which had never been operated on" [18, p. 68]; "he had a marked squint" [18, p. 70]; "her monstrous obesity" [18, p. 120].

It should be specifically emphasized that I. NechuyLevytsky's literary discourse is characterized by extensive use of similes, in particular in portrait descriptions. In the story "The Kaydash Family" the two brothers discuss the village girls as potential brides. The main point is that the brothers don't see eye to eye on the "merits" of the girls. Lavrin pictures his future bride as follows: «гарну, $я \kappa$ квіточка, червону, як калина в лузі, а тиху, як тихе літо», while Karpo favours a girl, who is "робоча, та проворна, та щоб була трохи куслива, як мухи в спасівку» [17, p. 156]. Each of the village girls is portrayed with considerable amount of humour. Thus, Palazhka - «брови, як шнурочки; моргне, ніби вогнем сипне. Одна брова варта вола, другій брові й ціни нема» versus «очі витрішкуваті, яку жаби, стан кривий, як у баби»; Khivria - «доладна, як писанка» versus «ходить таклегенько, наче в ступі горох товче»; Vivdia - «тиха, як ягниия» versus «тиха, як телиия» [17, p. 154]; Olena - «кругла, як цииулька, повновида, як повний місяџь; в неї щзоки, мов яблука, зуби, як біла ріпа, коса, як праник, сама дівка здорова, як тур» versus «товста, як бодня, а шия, хоч обіддя гни»; Odarka - «тоненька, як очеретина, гнучка станом, як тополя; личко маленьке й тоненьке, мов шовкова нитка; губи маленькі, як рутяний лист» [17, p. 155] versus «лице, як тріска, стан, наче копистка, руки, як кочерги, сама, як дошка, а як іде, то аж кістки торохтять» [17, p. 156].

Similes in portrait descriptions reflect sensitiveness of the Ukrainian people to natural beauty, be it of a mother to a child («два сини, неначе два соколи», «тихий, хоч у вухо бгай»; «сини неначе пахучі васильки на городi» [17, p. 172]) or of a young man to a young woman («гарна, як червона калина» [17, p. 199]; «гарна ж дівчина, як рай, мов червона рожа, повита барвінком» $[17$, р. 200]).

Conclusions. Portraiture nominations in both Ukrainian and English literary discourses denote: age; height and constitution; hair color and hair style; facial features; skin condition; form and color of eyes; traits of character; manner of behavior and speech; clothes and adornments; background, social status and profession. Having conducted a comparative analysis of portraiture nominations in the stories by I. Nechuy-Levytsky and W. S. Maugham, we have come to the conclusion that almost all types of characteristics in Ukrainian and English belleslettres discourses coincide. However, no portraiture nominations denoting physical defects have been traced in I. Nechuy-Levytsky's literary discourse.

Portraiture nominations represented by individual details help to create vivid and believable images of the characters and give the readers a deeper insight into the characters' personalities.

The prospects for further research can be seen in tracing possible distinctive features of portrait descriptions in male writers' and female writers' literary discourses.

\section{References:}

1. Абдуллина А. Ш. Портрет как важнейшее средство формирования целостного образа героя в прозе Н. Мусина. Фундаментальные исследования. 2014. № 5-6. C. 1343-1347. URL: http://www.fundamentalresearch.ru/ru/article/view?id=34096 (Last accessed: 18.12.2020).

2. Варлакова Е. А. Портретное описание протагониста в различных типах детективного текста. Becmник Череповеикого государственного университета. 2012. № 4. C. 49-52. URL: https://elibrary.ru/item. asp?id=17104517 (Last accessed: 03.01.2021). 
3. Вдовенко Т. А. Портретное описание глазами животных-повествователей в англоязычной художественной прозе. Перспективні наукові дослідження європейських мов, літератури та методик їх викладання : зб. наукових праць за матеріалами наук.-практ. конф. Ізмаїл : РВВ ІДГУ, 2017. С. 6-10.

4. Венжинович Н. Портретна характеристика людини у фраземіці української мови. Вісник Львівського університету. Серія філологічна. 2017. Вип. 64. Ч. ІІ. С. 360-365.

5. Галантер Б. Е. Живопись словом: Портрет, пейзаж, вещь. Москва : Советский писатель, 1974. 180 с.

6. Галич А. О. Портрет у мемуарному та біографічному дискурсах: семантика, структура, модифікації : монографія. Старобільськ : Вид-во ДЗ «Луганський нац. ун-т імені Тараса Шевченка», 2017. 449 с.

7. Литературная энциклопедия терминов и понятий / под. ред. А. Н. Николюкина. Москва : НПК «Интелвак», 2001. 1600 с.

8. Насалевич Т. В. Портретний опис у різних типах тексту : автореф. дис. на здобуття наук. ступеня канд. філол. наук : 10.02.04. Одеса, 2003. 16 с.

9. Словарь литературоведческих терминов / ред.-сост. Л. И. Тимофеев и С. В. Тураев. Москва : Просвещение, 1974. 509 с.

10. Трыков В. П. Французский литературный портрет XIX века. Москва : Флинта; Наука, 1999. 360 с.

11. Шинкевич О. Н. Портрет-описание как один из основных художественных приемов изображения литературного героя (на примере ранних повестей А. И. Куприна). Ученые записки Крымского федерального университета имени В. И. Вернадского. Филологические науки. 2017. Том 3 (69). № 3. С. 83-97.

12. Fowler E. Literary Character: The Human Figure in Early English Writing. Ithaca : Cornell University Press, 2003. 250 p.

13. Heier E. "The literary portrait" as a device of characterization. Neophilologus. 1976. № 60. P. 321-333. URL: https://doi.org/10.1007/BF01513762 (Last accessed: 15.12.2020).

14. Steiner W. The Semiotics of a Genre: Portraiture in Literature and Painting. Semiotics 1977. Vol. 21. Iss. 1-2. P. 111-120. URL: https://doi.org/10.1515/semi.1977.21.1-2.111 (Last accessed: 12.12.2020).

15. Theobald C. J. L. The Pose in Prose: The Literary Portrait and the Early French Psychological Novel : dissertation. University of Colorado. Denver, 2004. 460 p. URL: https://scholar.colorado.edu/concern/graduate thesis_or_dissertations/w6634383d (Last accessed: 03.01.2021).

\section{Illustrative material:}

16. Нечуй-Левицький I. Твори в двох томах. Том 1. Київ : Наукова думка, 1985. 640 c. URL: http://chtyvo. org.ua/authors/Nechui-Levytskyi/Tvory_v_dvokh_tomakh_Tom_1_zb/ (Last accessed: 10.12. 2020).

17. Нечуй-Левицький I. Твори в двох томах. Том 2. Київ : Наукова думка, 1986. 640 c. URL: http://chtyvo. org.ua/authors/Nechui-Levytskyi/Tvory_v_dvokh_tomakh_Tom_2_zb/ (Last accessed: 20.12. 2020).

18. Maugham W. S. Sixty-five Short Stories. William Heinemann Limited, 1988. 937 p.

\section{МИКИТюК І. М., ЛесінсЬКа О. М. НОМІНАЦІЇ ПЕРСОНАЖІВ У ПОРТРЕТНИХ ОПИСАХ: КОНТРАСТИВНЕ ДОСЛІДЖЕННЯ (НА МАТЕРІАЛІ УКРАЇНСЬКОМОВНОГО ТА АНГЛІЙСЬКОМОВНОГО ХУДОЖНІХ ДИСКУРСІВ)}

У статті розглянуто портретні описи персонажів в украӥнському (твори I. Нечуй-Левицького) та англійському (твори В. С. Моема) художньому дискурсі. Описано сучасний стан дослідження портрета як жанру художнього дискурсу. Особливу увагу зосереджено на виокремленні, інтерпретаиї таконтрастивномуаналізі ключовихлексем, якістворюють вербальніпортретиперсонажів. Актуальність запропонованогодослідженняполягаєуспробіздійснитиконтрастивнийаналізособливостейпортретизаиії персонажів у художніх текстах, написаних украйнською та англійською мовами. Саме контрастивний аналіз уможливлює висвітлення особливостей мовної картини світу мовців. На нашу думку, літературний портрет слугує потужнии засобом вербальної репрезентаиії персонажів у статичі та динаміиі, що досягається майстерним відображенням їхніх істотних рис та характеристик. Портретні описи в обох проаналізованих дискурсах можна згрупувати за такими характеристиками персонажів, як: вік (літній; a man of forty); зріст та будова тіла (гнучка, як тополя; tall, thin man); зачіска та колір волосся (товсті чорні коси; red hair); риси обличчя (повновида; fleshy face); стан шкіри (лице, свіже, як ягода; freckled skin); форма та колір очей (сині, як небо, очі; fine dark eуes); риси характеру (бриклива; reserved); манери поведінки та мовлення (пишала губи; raucous voice); одяг та прикраси (в квітках та стрічках; tweeds and heavy boots); походження, соџіальний статус та професія (був шевцем, стрільцем; wealthy banker). Зазначені характеристики повністю співпадають в обох аналізованих дискурсах. Проте в англомовному дискурсі нами зафіксовано номінації на позначення фізичних вад персонажів. Особисті характеристики, представлені у портретних описах, здатні створювати яскраві та переконливі образи персонажів, а також надавати читачам додаткових знань про особистості персонажів.

Ключові слова: портретна характеристика, характеризаиія, літературнийперсонаж, художній образ. 